\title{
GEOCHEMICAL INVESTIGATION AND MODELLING OF AN ACID PIT LAKE FROM A HIGH SULFIDATION ORE DEPOSIT: KIRKI, NE GREECE
}

\author{
Triantafyllidis S. ${ }^{1}$ and Skarpelis N. ${ }^{2}$ \\ ${ }^{1}$ Nikoforou 19, 16675 Glyfada, Athens, Greece, statrib@gmail.com \\ ${ }^{2}$ Faculty of Geology and Geoenvironment, University of Athens, Panepistimiopoli, 15784 Zografou, Athens, \\ Greece, skarpelis@geol.uoa.gr
}

\begin{abstract}
Open pit mining of a high sulfidation epithermal type deposit at Kirki (Thrace, NE Greece) resulted in the formation of an acid pit lake by infilling of the open cast by rain and drainage waters after mine closure. The acidic and oxidative pit lake waters show high concentrations of trace metals largely due to the high toxic metals content of the ore, the limited buffering capacity of host rocks and the direct exposure of the ore zone to weathering. The floor of the pit lake is covered by a finegrained mineral precipitate that comprises mainly detrital minerals, originating from erosion of the rocks exposed on the walls of the open pit. Secondary anglesite, several species of the jarosite-group, rozenite, melanterite, gypsum, bukovskyite, beaverite, scorodite and minor goethite are also detected. The mineral precipitate presents significant heavy metal content indicating effective removal of metals from the acidic waters. The speciation/mass transfer computer code PHREEQC-2 and the MINTEQ database were employed for geochemical modelling of the equilibrium between the acidic pit lake waters and the secondary phases of the mineral precipitate.
\end{abstract}

Key words: Acid pit lake, mineral precipitate, high-sulfidation ore, geochemical modelling, Kirki.

\section{Introduction}

Pit lakes are unique water bodies. They are developed as a result of open cast mining. When the activity ceases, the open pit is back filled with groundwater and surface water (Lu et al., 2003). The rate of filling is defined by climatic and geologic conditions, as well as the regional hydrologic characteristics.

Assessment of the environmental risks of pit lake development is an imperative for the mining industry and the public, especially in cases of high sulfidation deposits that are characterized by high concentrations of toxic metals (Plumlee et al., 1999). Pit lakes forming from such deposits pose a significant threat to the environment since they are often acidic containing elevated concentrations of metals (e.g. Fe, Al, Pb, Cu, Zn, Mn, Cd) and metalloids (e.g. As, Sb), and show high acid generation potential and very low buffering capacity (Latanzi et al., 2008; Sperling \& Grandschamp, 2008; Shevenell et al., 1999).

Quantification, prediction and evolution of pit lake systems require the use of numerical models (such as PHREEQC), which take into account the relevant thermodynamic, mineralogical and geochemical data, as well as other parameters such as changes in pit lake volume, effects of seasonal 


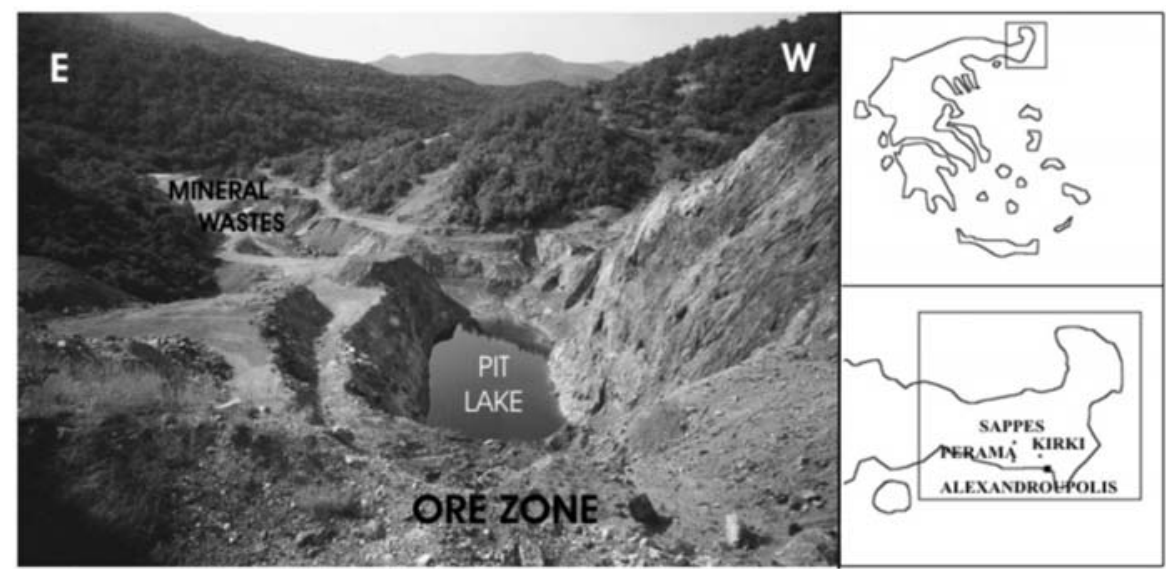

Fig. 1: View from north of the Kirki (Ag. Filippos) acid pit lake.

weather patterns, processes occurring on pit walls above the lake surface (Gimber et al., 2008). The aim of this paper is to provide information on the function of the small pit lake developed at the abandoned Kirki (Agios Filippos) high sulfidation mine. The results of this study can be used for future evaluation of various remediation options for the pit lake.

\section{Site description}

The Kirki (Agios Filippos) high sulfidation deposit is hosted into the Eocene-Oligocene volcano-sedimentary rock sequences of SE Evros county and is associated with orogenic calc-alkaline to shoshonitic magmatism. The high sulfidation epithermal type mineralization is developed between two sub-parallel fault zones that form the western and the eastern part of the open pit. The ore is rich in base-metals sulfides and various Pb- and As-bearing sulfosalts (Skarpelis, 1999). Galena shows the highest degree of weathering among other sulfides and sulfosalts. The low degree of oxidation of pyrite and sphalerite is reasonably explained by their rather chemical purity (Triantafyllidis \& Skarpelis, 2004). Studies by Triantafyllidis (2006) showed that in the upper part of the oxidation zone sulfates, hydrosulfates and sulfoarsenates are the predominant secondary mineral phases. Anglesite is the major oxidation product, followed by lower proportions of osarizawaite, beaverite, linarite and beudantite (Triantafyllidis \& Skarpelis, 2004). At lower levels of the oxidation zone, carbonates are additionally identified. Secondary carbonates include cerussite, hydrocerussite, smithsonite, azurite and rosasite. The mineralogy of efflorescences appearing on the walls of the open pit is indicative of highly acidic and oxidative conditions. Efflorescences of Fe-bearing (e.g. siderotile, copiapite, rhomboclase) and $\mathrm{Cu}$-bearing sulfates (e.g. chalcanthite), arsenates (scorodite) and sulfoarsenates dominate over $\mathrm{Pb}$ and $\mathrm{Zn}$ sulfates.

Since mine closure in 1997, an acid pit lake has been formed by infilling of the open pit by rain and drainage waters (Fig. 1). The height of the water column fluctuates, depending on the annual rainfall. The waters from the pit lake show low $\mathrm{pH}$, high Eh values and increased concentrations of dissolved toxic metals through the year (Triantafyllidis \& Skarpelis, 2006). The topography of the mine prevents overflow and dispersion of acidic waters into the drainage system of the area.

A yellowish to orange-yellowish, fine-grained, unconsolidated mineral precipitate with an average thickness of $20 \mathrm{~cm}$ covers the floor of the pit lake and yields significant heavy metal content. The mineral precipitate comprises mainly detrital quartz, dickite/kaolinite, pyrophyllite and feldspar, origi- 
nating from erosion of the rocks exposed on the walls of the open pit. Semiquantitative analyses indicate that Fe-bearing sulfates (jarosite group minerals, melanterite, rozenite, butlerite), sulfoarsenates (bukovskyite) and arsenates (scorodite) dominate over other secondary minerals (e.g. anglesite, beaverite, wroewolfeite and gypsum) (Triantafyllidis \& Skarpelis, 2006).

\section{Sampling - analytical methods}

Drill core samples down to a depth of $200 \mathrm{~m}$ from the surface were used for the mineralogical investigation of secondary mineral phases. Samples of mineral precipitate from the open pit and efflorescences from the mine walls were collected and dried at room temperature. Water samples from the open pit were collected in September 2001, June 2003 and December 2004, applying standard sampling techniques. Temperature, $\mathrm{pH}$ and Eh were measured on site using a WTW pH 320/Set-2 electronic $\mathrm{pH}$-meter. Water samples were filtered through a $0.45 \mu \mathrm{m}$ Millipore filter and acidified with $1 \mathrm{M} \mathrm{HNO3.} \mathrm{Details} \mathrm{of} \mathrm{the} \mathrm{analytical} \mathrm{technics} \mathrm{implemented} \mathrm{in} \mathrm{this} \mathrm{study} \mathrm{can} \mathrm{be} \mathrm{found} \mathrm{at} \mathrm{Tri-}$ antafyllidis (2006), Triantafyllidis \& Skarpelis (2006) and Triantafyllidis et al. (2007).

\section{Analytical data used}

The physicochemical data for the pit lake waters, the geochemical data of the mineral precipitate, and the mineralogy of the precipitate are given in Tables 1,2, and 3 respectively (Triantafyllidis \& Skarpelis, 2006).

Table 1. Physicochemical characteristics of pit lake waters (Dissolved ions in $\mathrm{mg} / \mathrm{lt}$, Eh in $\mathrm{mV}$ ) (from Triantafyllidis \& Skarpelis, 2006).

\begin{tabular}{|c|c|c|c|c|c|c|c|c|c|c|c|}
\hline & pH & Eh & SO $_{4}$ & Cd & Co & $\mathbf{C u}$ & Fe & Mn & Ni & Pb & Zn \\
\hline \multicolumn{10}{|c|}{ September 2001} \\
\hline Mean & 3.1 & 235 & 2300 & 3.82 & 0.26 & 16.2 & 7.5 & 169.7 & 1.76 & 2.24 & 425.5 \\
\hline Stan. Dev. & 0 & 1.58 & 130 & 0.07 & 0.01 & 0.25 & 0.26 & 3.4 & 0.03 & 0.03 & 1.22 \\
\hline \multicolumn{10}{|c|}{ June 2003} \\
\hline Mean & 2.9 & 248 & 1700 & 2.71 & 0.14 & 12.1 & 27.1 & 112.0 & 1.30 & 0.90 & 282.5 \\
\hline Stan. Dev. & 0.06 & 4.62 & 75 & 0.06 & 0.01 & 0.13 & 1.04 & 1.91 & 0.04 & 0.02 & 3.4 \\
\hline $\begin{array}{l}\text { Ag, Hg, As, Sb below detection } \\
\text { Total Radioactivity: } 16.48-151.62 \mathrm{pCi} / \text { lt }\end{array}$ \\
\hline
\end{tabular}

Table 2. Chemical analyses of the mineral precipitate (Major elements and Fe in wt \%, trace elements in ppm) (from Triantafyllidis \& Skarpelis, 2006

\begin{tabular}{|l|c|c|c|c|c|c|c|c|c|c|}
\hline & $\mathbf{S i O}_{2}$ & $\mathbf{A l}_{2} \mathbf{O}_{3}$ & $\mathbf{C a O}$ & $\mathbf{C r}_{2} \mathbf{O}_{3}$ & $\mathbf{K}_{2} \mathbf{O}$ & $\mathbf{M g O}$ & $\mathbf{N a}_{2} \mathbf{O}$ & $\mathbf{P}_{2} \mathbf{O}_{5}$ & $\mathbf{T i O}_{2}$ & $\mathbf{L O I}$ \\
\hline Min & 30.9 & 12.72 & 0.4 & 0.02 & 1.82 & 0.6 & 0.16 & 0.1 & 0.43 & 11.4 \\
\hline Max & 59.5 & 22.71 & 0.63 & 0.03 & 3.1 & 0.91 & 0.37 & 0.19 & 0.64 & 22.9 \\
\hline Mean & 43.8 & 17.5 & 0.52 & 0.02 & 2.39 & 0.76 & 0.28 & 0.14 & 0.55 & 18.4 \\
\hline Stan. Dev. & 12.1 & 4.4 & 0.09 & 0.01 & 0.58 & 0.14 & 0.09 & 0.03 & 0.1 & 5.16 \\
\hline \multicolumn{19}{l|l}{ LOI: Loss on ignition } \\
\hline
\end{tabular}


Table 2 continued.

\begin{tabular}{|l|c|c|c|c|c|c|c|c|c|c|c|c|c|}
\hline & $\mathbf{F e}$ & $\mathbf{P b}$ & $\mathbf{Z n}$ & $\mathbf{C u}$ & $\mathbf{M n}$ & $\mathbf{A s}$ & $\mathbf{C d}$ & $\mathbf{N i}$ & $\mathbf{S b}$ & $\mathbf{C o}$ & $\mathbf{A g}$ & $\mathbf{B i}$ & $\mathbf{U}$ \\
\hline Min & 6.21 & 3219 & 3195 & 473 & 591 & 497 & 22 & 22 & 26 & b.d. & 7.2 & 84 & b.d. \\
\hline Max & 20.78 & 6748 & 4789 & 958 & 2017 & 1582 & 46 & 31 & 38 & 20 & 11.3 & 136 & 11 \\
\hline Mean & 11.38 & 5087 & 4231 & 710 & 1256 & 889 & 32 & 25 & 31 & 4 & 8.9 & 98 & 6 \\
\hline Stan. Dev. & 5.91 & 1050 & 621 & 147 & 577 & 475 & 7.3 & 3 & 5.6 & 6.6 & 1,5 & 28 & 4.4 \\
\hline
\end{tabular}

Hg: below detection limit

b.d.: below detection

Table 3. Semiquantitative analyses of secondary minerals identified in the mineral precipitate (from Triantafyllidis \& Skarpelis, 2006).

\begin{tabular}{|l|l|c|}
\hline $\begin{array}{l}\text { Jarosite group minerals } \\
\text { (jarosite, hydronium jarosite) }\end{array}$ & $\left(\mathrm{K}, \mathrm{H}_{3} \mathrm{O}\right) \mathrm{Fe}_{3}\left(\mathrm{SO}_{4}\right)_{2}(\mathrm{OH})_{6}$ & $\mathrm{XXX}$ \\
\hline Wroewolfeite & $\mathrm{Cu}_{4}\left(\mathrm{SO}_{4}\right)(\mathrm{OH})_{6} \cdot 2 \mathrm{H}_{2} \mathrm{O}$ & $\mathrm{X}$ \\
\hline Beaverite & $\mathrm{PbCu}\left(\mathrm{Fe}, \mathrm{Al}_{2}\left(\mathrm{SO}_{4}\right)_{2}(\mathrm{OH})_{6}\right.$ & $\mathrm{XX}$ \\
\hline Gypsum & $\mathrm{CaSO}_{4} \cdot 2 \mathrm{H}_{2} \mathrm{O}$ & $\mathrm{XX}$ \\
\hline Anglesite & $\mathrm{PbSO}_{4}$ & $\mathrm{XX}$ \\
\hline Scorodite & $\mathrm{FeAsO}_{4} \cdot 2 \mathrm{H}_{2} \mathrm{O}$ & $\mathrm{X}$ \\
\hline Bukovskyite & $\mathrm{Fe}_{2}\left(\mathrm{AsO}_{4}\right)\left(\mathrm{SO}_{4}\right)(\mathrm{OH}) \cdot 7 \mathrm{H}_{2} \mathrm{O}$ & $\mathrm{XX}$ \\
\hline Goethite & $\mathrm{Fe}_{(\mathrm{OH})_{3}}$ & $\mathrm{X}$ \\
\hline Melanterite & $\mathrm{FeSO}_{4} \cdot 7 \mathrm{H}_{2} \mathrm{O}$ & $\mathrm{X}$ \\
\hline Rozenite & $\mathrm{FeSO}_{4} \cdot 4 \mathrm{H}_{2} \mathrm{O}$ & $\mathrm{X}$ \\
\hline Butlerite & $\mathrm{FeSO}_{4}(\mathrm{OH}) \cdot 2 \mathrm{H}_{2} \mathrm{O}$ & \\
\hline Mineral abundances: $\mathrm{XXX}$ very abundant, $\mathrm{XX} \mathrm{medium,} \mathrm{X}$ low & \\
\hline
\end{tabular}

\section{Application of PHREEQC geochemical code}

The correlation between the chemistry of the acidic pit lake waters and the mineralogy of the mineral precipitate was investigated with the use of the geochemical code PHREEQC-2 (Parkhurst \& Appelo, 1999) and in particular the 2.12 edition.

There are two basic approaches to geochemical modeling: chemical equilibrium and chemical kinetics, with the first, and most common, being employed in this study. In general, equilibrium models can be divided into the following categories: forward (reaction path models) and inverse.

Forward models are used for prediction of water chemistry evolution. In this case the starting water chemistry is defined and an attempt is made to model water evolution by precipitation of mineral phases. During each step the program transfers a small amount of mass from reactant to products. Then it calculates mass distribution among the products and saturation indices of pre-determined phases. Then, the program checks whether the water is supersaturated relative to those phases.

Inverse models are based on mass balance calculations for solid phase and dissolved species in a geochemical system. In this case, we examined the precipitation of the mineral phases identified in the pit lake after mixing of two different water types. 
Table 4.

\begin{tabular}{|c|c|c|c|}
\hline \multicolumn{4}{|c|}{ Physicochemical characteristics of the solutions used for PHREEQC modeling } \\
\hline Solution 1 (meteoric waters) & \multicolumn{2}{c|}{ Solution 2 (acidic pit lake waters) } \\
\hline Temperature & $25^{\circ} \mathrm{C}$ & Temperature & $25^{\circ} \mathrm{C}$ \\
\hline $\mathrm{pH}$ & 6 & $\mathrm{pH}$ & 3 \\
\hline $\mathrm{p} \varepsilon$ & 4 & $\mathrm{p} \varepsilon$ & 4 \\
\hline density & $1 \mathrm{gr}^{-\mathrm{cm}^{3}}$ & density & $1 \mathrm{~g} / \mathrm{cm}^{3}$ \\
\hline & & $\left.\mathrm{S}(\mathrm{as} \mathrm{SO})_{4}\right)$ & $2300 \mathrm{mg} / \mathrm{L}$ \\
\hline & & $\mathrm{Cu}$ & $16 \mathrm{mg} / \mathrm{L}$ \\
\hline & & $\mathrm{Mn}$ & $170 \mathrm{mg} / \mathrm{L}$ \\
\hline & & $\mathrm{Zn}$ & $425 \mathrm{mg} / \mathrm{L}$ \\
\hline & & $\mathrm{Fe}$ & $7 \mathrm{mg} / \mathrm{L}$ \\
\hline & & $\mathrm{Pb}$ & $2 \mathrm{mg} / \mathrm{L}$ \\
\hline & & $\mathrm{Na}$ & $10 \mathrm{mg} / \mathrm{L}$ \\
\hline & & $\mathrm{K}$ & $2 \mathrm{mg} / \mathrm{L}$ \\
\hline
\end{tabular}

\section{Geochemical modeling}

Thermodynamic data was taken from MINTEQ database (Allison et al., 1991). Imported parameters in the system involved: $\mathrm{Fe}$ (total), $\mathrm{Pb}, \mathrm{Zn}, \mathrm{Cu}, \mathrm{Mn}, \mathrm{SO}_{4}^{-2}$ and $\mathrm{pH}$. Cobalt was not taken under consideration since it is not included in the MINTEQ database. Several different scenarios were employed for the system "acidic pit lake waters - precipitate mineralogy".

\subsection{Forward modeling}

The first scenario involved the possibility of direct precipitation of the identified secondary phases, as a result of supersaturation due to evaporation, or excessive input of toxic metals, sulfates and arsenates to the pit lake, at a given time period. Application of the PHREEQC geochemical code showed that direct precipitation is impossible largely due to the low heavy metal and sulfate load of the pit lake waters.

\subsection{Inverse modeling}

Inverse modeling was applied to verify hypotheses on the origin of the identified secondary phases in the mineral precipitate. Two cases were examined. The first case involved the study of the chemical characteristics of a theoretical solution that resulted after mixing slightly acidic meteoric water (Table 4, solution 1) with a potential acid drainage in several ratios, to check if that solution is in equilibrium with the secondary phases identified in the precipitate. For the second case, the acidic pit lake waters were used as the potential acid drainage (Table 4, solution 2). Once more, the behavior of mixing the slightly acidic rain water with the potential acid drainage in several ratios was investigated.

$\mathbf{1}^{\text {st }}$ case: The potential acid drainage was based on thermodynamic data from MINTEQ database. The mineralogy of the Kirki high sulfidation deposit is very complex with a diversity of sulfides and sulfosalts and, unfortunately, for most of these minerals there is no data. This geochemical model showed that potential acid drainage with thermodynamic data only for pyrite, galena and sphalerite cannot sufficiently interpret the secondary mineralogy of the precipitate. 
Table 5.

\begin{tabular}{|l|c|l|}
\hline \multicolumn{3}{|c|}{$\begin{array}{c}\text { Saturation indices of secondary minerals in equilibrium with the acidic pit lake waters, } \\
\text { based on the PHREEQ-2.12 geochemical code }\end{array}$} \\
\hline Mineral & Saturation index (MINTEQ) & Formula (MINTEQ) \\
\hline Anglesite & 0.66 & $\mathrm{PbSO}_{4}$ \\
\hline Bianchite & -4.93 & $\mathrm{ZnSO}_{4} \times 6 \mathrm{H}_{2} \mathrm{O}$ \\
\hline Cerussite & -1.62 & $\mathrm{PbCO}_{3}$ \\
\hline Ferrihydrite & -1.58 & $\mathrm{Fe}(\mathrm{OH})_{3}$ \\
\hline Goethite & 2.82 & $\mathrm{FeOOH}$ \\
\hline Goslarite & -4.74 & $\mathrm{ZnSO}_{4} \times 7 \mathrm{H}_{2} \mathrm{O}$ \\
\hline Hematite & 10.64 & $\mathrm{Fe}_{2} \mathrm{O}_{3}$ \\
\hline H3O-jarosite & 0.94 & $\left(\mathrm{H}_{3} \mathrm{O}\right) \mathrm{Fe}_{3}\left(\mathrm{SO}_{4}\right)_{2}(\mathrm{OH})_{6}$ \\
\hline Jarosite & 1.87 & $\mathrm{KFe}_{3}\left(\mathrm{SO}_{4}\right)_{2}(\mathrm{OH})_{6}$ \\
\hline Na-jarosite & -0.89 & $\mathrm{NaFe}_{3}\left(\mathrm{SO}_{4}\right)_{2}(\mathrm{OH})_{6}$ \\
\hline Larnackite & -3.42 & $\mathrm{PbOxPSO}_{4}$ \\
\hline Lepidocrockite & 1.94 & $\mathrm{FeOOH}_{3}$ \\
\hline Maghemite & 0.24 & $\mathrm{Fe}_{2} \mathrm{O}_{3}$ \\
\hline Magnetite & 5.07 & $\mathrm{Fe}_{3} \mathrm{O}_{4}$ \\
\hline Melanterite & -5.91 & $\mathrm{FeSO}_{4} \mathrm{x}_{7} \mathrm{H}_{2} \mathrm{O}$ \\
\hline Smithsonite & -4.33 & $\mathrm{ZnCO}_{3}$ \\
\hline
\end{tabular}

$2^{\text {nd }}$ case: Development of this model with PHREEQC, for mixing of the aforementioned solutions in ratio 95:5 (95\% solution 1 and 5\% solution 2), leads to a final solution that is in equilibrium with the majority of the secondary phases identified in the pit lake mineral precipitate (e.g. anglesite, goethite, jarosite), as well as other secondary phases that cannot be detected with X-ray Diffractometry (e.g ferrihydrite) (Table 5).

It is worth mentioning that similar results arise with different mixing ratios (e.g. 99 to 1). Another characteristic of this model is the thermodynamic equilibrium of several secondary Fe phases, while the concentration of Fe in the acidic pit lake water are relatively low (7.5 to $27 \mathrm{mg} / \mathrm{L})$.

\section{Conclusions}

The Kirki (Agios Filippos) high sulfidation deposit is rich in base metals sulfides (e.g. pyrite, galena, sphalerite) and sulfosalts (e.g. enargite, tennantite, jordanite). Lead and $\mathrm{Cu}$-bearing sulfates and hydrosulfates dominate in the upper part of the oxidation zone of the Kirki deposit, whereas at lower levels supergene carbonates are present. During the last ten years, an acid pit lake was formed by infilling of the open pit by rain and drainage waters. The highly acidic pit lake waters show high concentrations of dissolved toxic metals. The pit lake waters are characterized by increased toxic metals concentrations as a result of:

- Oxidation of sulfides and sulfosalts and the partial release of their toxic load to the environment due to the presence of mildly acidic and oxidative meteoric and drainage waters. 
- Washing and dissolution of soluble secondary phases (efflorescences) formed on the walls of the open pit.

- The direct contact of the highly acidic and oxidative waters of the pit lake with grains of sulfides and sulfosalts present at the level of pit lake water.

The model developed with PHREEQC for the Kirki pit lake system shows that meteoric waters plays a key role in deposition of secondary phases in the pit lake. In particular, mixing of slightly acidic meteoric waters with the acidic pit lake waters in ratio 95:5 or higher, may successfully lead to the formation of anglesite, goethite, jarosite group minerals, hematite and ferrihydrite. On the other hand, due to lack of thermodynamic data, there are no conclusions concerning beaverite, scorodite, bukovskyite, wroewolfeite and siderotile.

Finally, it is very important to state that the aforementioned model for the Kirki pit lake system is based on a critical limitation, being the organic activity within the pit lake waters. It is known that the role of aerobic bacteria is critical in the initial oxidation/weathering of primary sulfides and sulfosalts (Stokes, 1954; Walsh \& Mitchell, 1972; Trafford et al., 1973; Ivarson \& Sojak, 1978; Crepar et al., 1979; Evangelou, 1983), as well as their catalytic behavior in the formation of secondary phases present in pit lakes precipitates. Further study aims to shed light on the role bacteria play for the evolution of the Kirki pit lake system.

\section{Acknowledgements}

The research work was funded through the program "IRAKLEITOS - Fellowships for Research of National and Kapodistrian University of Athens - ENVIRONMENT".

\section{References}

Allison, J.D., Brown, D.S. \& Novo-Gradac, K.J., 1991. MINTEQA2/PRODEFA2, A geochemical assessment model for environmental systems, Version 3.0 User's Manual, Environmental Research Laboratory, Office of Research and Development, US Environmental Protection Agency, EPA/600/391/021, Athens, Georgia, 30605, 92.

Crepar, D.A., Knox, G.W. \& Means, J.L., 1979. Biogeochemistry of bog iron in the New Jersey pine barrens. Chemical Geology, 24, 111-135.

Enders, M.S., Knickerbocker, C., Titley \& Southam, G., 2006. The role of bacteria in the supergene environment of the Morenci Porphyry Copper Deposit, Greenlee County, Arizona. Economic Geology, 101, 59-70.

Evangelou, V.P., 1983. Pyritic coal spoils: Their chemistry and water interactions. In S.S. Augustithis (eds), Leaching and diffusion in rocks and their weathering products, Theophrastus Publications S,A., Athens, Greece, 175-228.

Gimber C., Preda, M., Scott, P. \& McCombe, C., 2008. Geochemical Assessment and Modelling of Open Cut Pit, Mount Morgan, Queensland, Australia. In O. Totolo, (ed.) Book of Proceedings, Water Resource Management 2008 (Africa WRM 2008), Gaborone, Botswana, Africa, 8-10 September, 2008, $248 \mathrm{p}$.

Ivarson, K.C. \& Sojak, M., 1978. Microorganisms and ochre deposits in field drains of Ontario. Canadian Journal of Soil Science, 58, 1-17.

Lattanzi, P., Da Pelo, S., Musu, E., Atzei, D., Elsener, B., Fantauzzi, M. \& Rossi, A., 2008. Enargite oxidation: a review. Earth Science Reviews, 86, 62-88.

Lu, M., Carlsson, E. \& Ohlander, B., 2003. Limnological and geochemical comparisons of two sulphide 
mine lakes. In Book of Proceedings of the 10th International Conference, Tailings and Mine Waste 03, Vail, Colorado, 12-15 October 2003, Swetz and Zeitlinger B.V., Lisse, Netherlands, 523p.

Parkhurst, D.L. \& Appelo, C.A.J., 1999. User's guide to PHREEQC (version 2) - a computer program for speciation, batch-reaction, one-dimensional transport and inverse geochemical calculations. U.S. Geological Survey, Denver, Colorado, report 99-4259.

Plumlee, G.S., Smith, K.S., Montour, M.R., Ficklin, W.H. \& Mosier, E.L., 1999. Geologic controls on the composition of natural waters and mine waters draining diverse mineral-deposit types. In L.H Filipek \& G.S. Plumlee (eds.), Reviews in Economic Geology, 6B. The Environmental Geochemistry of Mineral Deposits. Part B: Case Studies and Research Topics, Society of Economic Geologists, 373-432.

Skarpelis, N., 1999. The Agios Filippos ore deposit, Kirki (Western Thrace). A base metal part of a high sulfidation epithermal system. Bulletin of the Geological Society of Greece, 33, 51-60.

Shevenell, L., Connors, K.A. \& Henry, C.D., 1999. Controls on pit lake water quality at sixteen open-pit mines in Nevada. Applied Geochemistry, 14, 669-687.

Sperling, E. \& Grandschamp, C.A.P., 2008. Possible water uses in mining lakes: case study of Agua Claras, Brazil. 33 ${ }^{\text {rd }}$ WDEC International Conference, 375-380.

Stokes, J.L., 1954. Studies in the filamentous iron bacterium Sphaerotilus natans. Journal of Bacteriology, 67, 278-291.

Trafford, B.D., Bloomfield, C., Kelso, W.I. \& Pruden, G., 1973. Ochre formation in field drains in pyritic soils. Journal of Soil Science, 24, 453-460.

Triantafyllidis, S., 2006. Environmental risk assessment of mining and processing activities and rehabilitation proposals in Evros and Rhodope prefectures (Thrace, NE Greece). Unpublished $\mathrm{PhD}$ Thesis (in Greek). National and Kapodistrian University of Athens, Faculty of Geology and Geoenvironment, Department of Economic Geology and Geochemistry, 307p.

Triantafyllidis, S. \& Skarpelis, N., 2004. A mineralogical approach to understanding dispersion of toxic elements around high sulfidation epithermal deposits: the case of Kirki, N. Greece. In Z. Agioutantis and K. Komnitsas (eds), Proceedings of the $1^{\text {st }}$ International Conference in Advances in Mineral Resources Management and Environmental Geotechnology (AMIREG), Hania, Greece, 739-744.

Triantafyllidis, S. \& Skarpelis, N. (2006) Mineral formation in an acid pit lake from a high-sulfidation ore deposit: Kirki, NE Greece. Journal of Geochemical Exploration, 88, 68-71.

Triantafyllidis, S. \& Skarpelis, N. \& Komnitsas, K. (2007) Environmental characterization and geochemistry of Kirki, Thrace, NE Greece, abandoned flotation tailing dumps. Environmental Forensics, 8, 351-359.

Walsh, F. \& Mitchell, R., 1972. A pH-dependent succession of iron bacteria. Environmental Science and Technology, 6, 809-812. 